\title{
LITERASI BACA TULIS DAN KAITANNYA \\ DENGAN PENGEMBANGAN MATERI AJAR BAHASA INDONESIA
}

\section{Putri Kartika Oktiana}

\section{Program Magister Fakultas Bahasa dan Seni, Universitas Negeri Padang \\ p.kartika02@gmail.com}

Literasi baca dan tulis adalah pengetahuan dan kecakapan untuk membaca, menulis, mencari, menelusuri, mengolah, dan memahami informasi untuk menganalisis, menanggapi, dan menggunakan teks tertulis untuk mencapai tujuan mengembangkan pemahaman dan potensi. Membaca dan menulis sangat berarti dalam ilmu dan pengetahuan, terlebih lagi perkembangan zaman memiliki tantangan, persaingan, dan pergerakan teknologi yang pesat hal ini sangat mempengaruhi dunia pendidikan. Penelitian dari (Indriyani et al., 2019) dan (Agusrida et al., 2020) menjelaskan perkembangan ilmu pengetahuan dan teknologi menciptakan masyarakat yang terus berupaya untuk meningkatkan kemampuan, terutama dalam bidang pendidikan. Pendidikan yang berkualitas tersebut ditandai salah satunya dengan masyarakat literat. Oleh karena itu, guru juga dituntut beradaptasi dengan perkembangan teknologi, menciptakan sebuah pembelajaran yang menyenangkan seperti menggunakan media yang tepat karena dunia pendidikan terus mengikuti perkembangan zaman. Hal ini sangat menguji eksistensi guru dalam menekun profesinya dalam kegiatan mengajar. Kaitannya dengan literasi baca tulis yaitu mengantar peserta didik ke arah kreatifitas yang lebih baik dalam mengembangkan ide, gagasan, serta luas pengetahuan dalam pembelajaran.

Media digital dalam kegiatan literasi baca tulis materi ajar bahasa Indonesia dapat kita terapkan pada kegiatan membaca karya sastra dengan menggunakan aplikasi wattpad yang memudahkan membuat sebuah karya sastra seperti novel dan cerpen atau sebagai pembaca, observasi, bahkan mengamati langsung suatu objek. Kegiatan ini juga dapat diterapkan dengan merancang sebuah modul untuk memudahkan siswa dalam melaksanakan pembelajaran. Mengutip penelitian terdahulu dari (Joyo, 2018; Mulyadi et al., 2020; Winita et al., 2020) bahwa guru harus membuat sebuah konsep pembelajaran yang menyenangkan dengan menggunakan media digital sebagai acuan materi utama. Media digital yang diciptakan sebaik mungkin dapat membantu siswa kegiatan literasi baca tulis dan mengembangkan potensi yang telah didukung oleh pengamatan, pengalaman, bahkan gambaran yang pernah diamati oleh siswa.

Menciptakan sebuah media yang baik tentunya memastikan gaya belajar generasi sekarang dapat terpenuhi agar strategi yang diterapkan harus disesuaikan dengan kebutuhan mereka. Oleh karena itu, perkembangan yang pesat dapat menjadi pendorong bagi peserta didik untuk berinovasi dan meningkatkan metode belajar dan berkreasi dalam menciptakan sebuah karya. Hal ini sesuai dengan penelitian terdahulu dari (Kurnianingsih et al., 2017; Syahrul Ramadhan et al., 2021) bahwa media digital dalam kegiatan litersi mampu membuat dan berbagi 
dalam mode dan bentuk yang berbeda; untuk membuat, berkolaborasi, dan berkomunikasi lebih efektif. Oleh karena itu, penggunaan media digital berpotensi besar untuk memberdayakan kemampuan berpikir tingkat tinggi siswa.

Menggerakan budaya membaca dan menulis sejak dini sangat penting karena potensi perkembangan zaman terus berlanjut dan tidak berhenti dalam mengembangkan inovasi pembelajaran. (S. Ramadhan et al., 2019) dalam penelitiannya menjelaskan perlunya pengembangan profesional guru dalam literasi media digital bukanlah pilihan melainkan kewajiban. Kemajuan dalam bidang pendidikan dalam memperoleh informasi dengan menggunakan berbagai media digital tidak dapat dihindarkan. Maka dari itu, guru harus menciptakan sebuah edukasi yang terbaru dan kreatif agar mudah dalam melaksanakan pembelajaran dan menciptakan pembelajaran yang menyenangkan bagi siswa serta harus menguasai teknologi karena menjadi tantang profesi yang dihadapi. Kegiatan literasi dalam pelajaran bahasa Indonesia dapat kita amati melalui pembelajaran mengamati, observasi, bahkan mengapresiasi suatu karya sastra agar mampu mengembangkan potensi diri dalam menulis, bersosialisasi, bahkan berkreatifitas dalam menguasai bidang informasi dan komunikasi.

\section{DAFTAR PUSTAKA}

Agusrida, Atmazaki, Syahrul, R., \& Ermanto. (2020). Effectiveness of Online Scientific Publication Training Approach for Teacher's Professional Competence Development at Religious Training Centre in Padang. 504(ICoIE), 370-375.

Indriyani, V., Zaim, M., Atmazaki, A., \& Ramadhan, S. (2019). Literasi Baca Tulis Dan Inovasi Kurikulum Bahasa. KEMBARA: Jurnal Keilmuan Bahasa, Sastra, Dan Pengajarannya, 5(1), 108.

Joyo, A. (2018). Kata Kunci: Literasi, Kearifan Lokal, Karakter. Jurnal KIBASP (Kajian Bahasa, Sastra Dan Pengajaran), 1(2), 159-170.

Kurnianingsih, I., Rosini, R., \& Ismayati, N. (2017). Upaya Peningkatan Kemampuan Literasi Digital Bagi Tenaga Perpustakaan Sekolah dan Guru di Wilayah Jakarta Pusat Melalui Pelatihan Literasi Informasi. Jurnal Pengabdian Kepada Masyarakat (Indonesian Journal of Community Engagement), 3(1), 61.

Mulyadi, Syahrul, R., Atmazaki, \& Agustina. (2020). The Development of E-Modules Based on Adobe Flash for Indonesian Subjects at IAIN Bukittinggi. Journal of Physics: Conference Series, 1471(1).

Ramadhan, S., Sukma, E., \& Indriyani, V. (2019). Teacher competence in utilizing digital media literacy in education. Journal of Physics: Conference Series, 1339(1).

Ramadhan, Syahrul, Atmazaki, Sukma, E., \& Indriyani, V. (2021). Multimedia with Social Learning Networks (SNL): As Learning Innovation in the 4.0 Industrial Era. Journal of Physics: Conference Series, 1779(1), 0-9.

Winita, S., Ramadhan, S., \& Asri, Y. (2020). The Development of Electronic Module Based on 
Discovery Learning in Writing Explanation Text. 463, 63-69. 